\title{
Analysis study the used of Tuned Mass Damper (TMD) on an existing train bridge due to high speed train with moving mass load approach
}

\author{
Wivia Octarena Nugroho ${ }^{1, *}$, Dina Rubiana Widarda ${ }^{1}$, and Oryza Herdha Dwyana ${ }^{1}$ \\ ${ }^{1}$ Civil Engineering Department, Universitas Katolik Parahyangan, Bandung, Indonesia
}

\begin{abstract}
As the need of the train speed increased, the existing bridges need to be evaluated, especially in dynamic responses, which are deformation and acceleration. In this study, Cisomang Bridge is modeled and analyzed due to the high-speed train SJ X2 in varying speeds, $50 \mathrm{~km} / \mathrm{h}, 100 \mathrm{~km} / \mathrm{h}, 150 \mathrm{~km} / \mathrm{h}$, and $200 \mathrm{~km} / \mathrm{h}$. The used of tuned mass damper also will be varied on its setting and placing. The tuned mass dampers setting be varied based on the first or second natural frequency and the placing of tuned mass damper be varied based on maximum deformation of the first or second mode. Moreover, the tuned mass damper ratio will be varied $1 \%$ and $1.6 \%$. For all speed variations, dynamic responses of structure without TMD still fulfil the Indonesian Government Criterion based on PM 60 - 2012 but do not meet requirement of comfort criteria based on DINFachbericht 101. Furthermore, only for the speed train $50 \mathrm{~km} / \mathrm{h}$ dynamic responses of structure fulfil safety criteria based on Eurocode EN 1990:2002, whereas the other speed variations do not meet that requirement. In the use of TMD 1\% mass ratio, the structure fulfils the safety criteria for all speed variations. In the use of TMD 1.6\% mass ratio, all the structure fulfils the safety and comfort criteria except $100 \mathrm{~km} / \mathrm{h}$ speed which only fulfils the safety criteria.
\end{abstract}

\section{Introduction}

The high demand traffic triggers the development of high speed train in Indonesia, even new infrastructure will be built to accommodate "high speed train Jakarta-Bandung" by Indonesian Government. However, the construction of new infrastructure will be cost and time consuming. Cisomang Railway Bridge is one of existing bridges located in Jakarta-Bandung Line. It is interesting to evaluate whether high speed trains are able to go through the existing Cisomang Railway Bridge.

Zhang et al [9] have studied that train speed increase bridge acceleration, whereas some provisions state that bridge must fulfils safety and comfort criteria based on its acceleration [4 5]. The excessive vibration might be happened to the existing Cisomang Railway Bridge which was not designed for high speed train previously. Some works [6 7] have studied the reducing structural responses with the use of TMD. Kwon et al [6] studied three-span bridge under TGV train whereas Wang et al [7] studied simply supported bridge under three various trains: French T.G.V., German I.C.E, and Japanese S.K.S. In this study, Cisomang Railway Bridge will be analysed under high speed train SJ X2. Dynamic responses of Cisomang Railway Bridge will be evaluated, which are structure's displacement and acceleration. If the structure's responses exceed the limit, TMD will be used to reduce them. This study aimed to analyse the existing structure's responses due to high speed train before and after the used of TMD. The location and setting properties of TMD installation will be varied in several structural modes. The mass ratio of TMD also will be varied. All variation is made to find which one is the most effective.

\section{Case Study}

The bridge to be analysed is $244.3 \mathrm{~m}$ Cisomang Railway Bridge located above Cisomang River, Purwakarta, West Java as shown in Figure 1 and Figure 2. The bridge has 16 supports which are 8 fixed supports located on truss piers, 4 pinned supports located on abutment and 4 pinned supports located on the arch as shown in Figure 3. The bridge has various truss pier height dimension that can be shown in Figure 4.

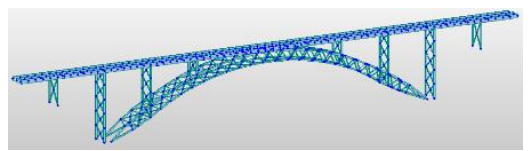

Fig. 1. Cisomang Railway Bridge

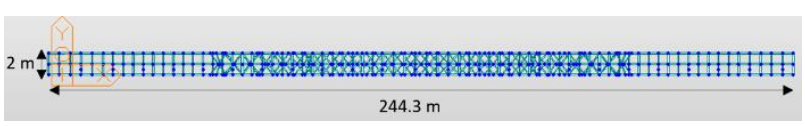

Fig. 2. Plan Layout Cisomang Railway Bridge

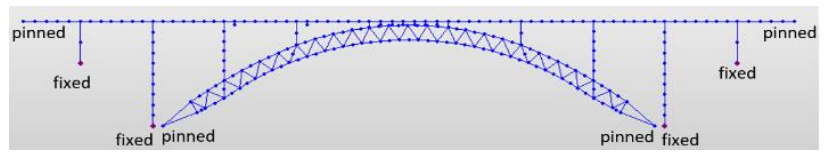

Fig. 3. The Supports of The Bridge

\footnotetext{
* Corresponding author: wivia.octarena $@$ gmail.com
} 


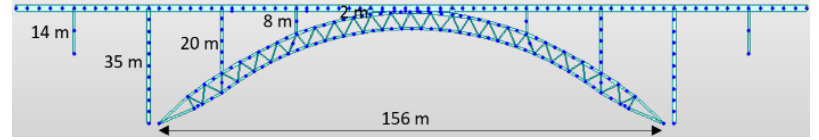

Fig. 4. Truss Pier Height Dimension

There are 2 variations of TMD mass, which are $1 \%$ and $1.6 \%, 2$ variations of TMD setting, which are first and second structure's mode frequencies, and 2 variations of TMD location, which are first and second structure's mode maximum deformations. So, there are 8 models in total as described in Table 1 .

Table 1. Model Case study

\begin{tabular}{|c|c|c|c|}
\hline \multirow{2}{*}{\multicolumn{2}{|c|}{$\begin{array}{c}1 \% \text { Mass Ratio of } \\
\text { TMD }\end{array}$}} & \multicolumn{2}{|c|}{ Location } \\
\hline & & \multirow{2}{*}{$\begin{array}{c}\text { Max } \\
\begin{array}{c}\text { Deformation } \\
\text { of First Mode }\end{array} \\
\text { Model } 1\end{array}$} & \multirow{2}{*}{$\begin{array}{c}\text { Max } \\
\text { Deformation of } \\
\text { Second Mode } \\
\text { Model } 3\end{array}$} \\
\hline \multirow{2}{*}{ Setting } & $\begin{array}{l}\text { Frequency } \\
\text { of First } \\
\text { Mode }\end{array}$ & & \\
\hline & $\begin{array}{c}\text { Frequency } \\
\text { of Second } \\
\text { Mode }\end{array}$ & Model 2 & Model 4 \\
\hline \multirow{2}{*}{\multicolumn{2}{|c|}{$\begin{array}{c}1.6 \% \text { Mass Ratio of } \\
\text { TMD }\end{array}$}} & \multicolumn{2}{|c|}{ Location } \\
\hline & & $\begin{array}{c}\text { Max } \\
\text { Deformation } \\
\text { of First Mode }\end{array}$ & $\begin{array}{c}\text { Max } \\
\text { Deformation of } \\
\text { Second Mode }\end{array}$ \\
\hline \multirow{2}{*}{ Setting } & $\begin{array}{l}\text { Frequency } \\
\text { of First } \\
\text { Mode }\end{array}$ & Model 5 & Model 7 \\
\hline & $\begin{array}{l}\text { Frequency } \\
\text { of Second } \\
\text { Mode }\end{array}$ & Model 6 & Model 8 \\
\hline
\end{tabular}

The material used for Cisomang Railway Bridge is steel with material specifications S355J0 and S235J0. Material properties of S355J0 can be seen in Table 2 and S235J0 material properties can be seen in Table 3 .

Table 2. S355J0 Material Properties

\begin{tabular}{|c|c|c|}
\hline $\begin{array}{c}\text { Nominal } \\
\text { thickness }(\mathrm{t}) \\
(\mathrm{mm})\end{array}$ & $\begin{array}{c}\text { Minimum } \\
\text { yield strength } \\
(\mathrm{MPa})\end{array}$ & $\begin{array}{c}\text { Tensile } \\
\text { strength }(\mathrm{MPa})\end{array}$ \\
\hline $\mathrm{t} \leq 16$ & 355 & $479-630$ \\
\hline $16<\mathrm{t} \leq 40$ & 345 & $479-630$ \\
\hline $40<\mathrm{t} \leq 63$ & 335 & $479-630$ \\
\hline $63<\mathrm{t} \leq 80$ & 325 & $479-630$ \\
\hline $80<\mathrm{t} \leq 100$ & 315 & $479-630$ \\
\hline $100<\mathrm{t} \leq 125$ & 295 & $479-630$ \\
\hline
\end{tabular}

Table 3. S235J0 Material Properties

\begin{tabular}{|c|c|c|}
\hline $\begin{array}{c}\text { Nominal } \\
\text { thickness }(\mathrm{t}) \\
(\mathrm{mm})\end{array}$ & $\begin{array}{c}\text { Minimum } \\
\text { yield strength } \\
(\mathrm{MPa})\end{array}$ & $\begin{array}{c}\text { Tensile } \\
\text { strength (MPa) }\end{array}$ \\
\hline $\mathrm{t} \leq 16$ & 235 & $360-510$ \\
\hline $16<\mathrm{t} \leq 40$ & 225 & $360-510$ \\
\hline $40<\mathrm{t} \leq 63$ & 225 & $360-510$ \\
\hline $63<\mathrm{t} \leq 80$ & 215 & $360-510$ \\
\hline $80<\mathrm{t} \leq 100$ & 215 & $360-510$ \\
\hline $100<\mathrm{t} \leq 125$ & 195 & $360-510$ \\
\hline
\end{tabular}

The sections used for Cisomang Railway Bridge are IWF (Figure 5a) listed on Table 4, hollow section (Figure 5b) list on Table 5, and tapered section (Figure 5c) listed on Table 6.

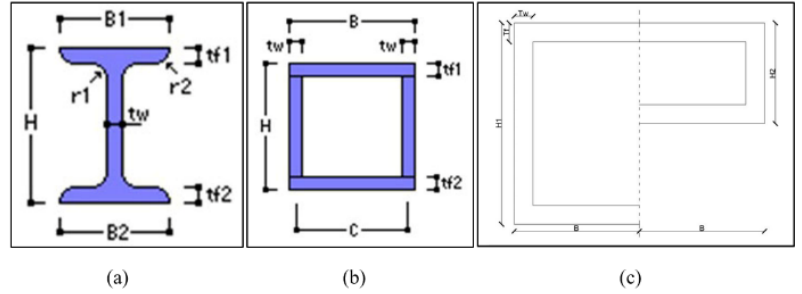

Fig. 5. Section used for Cisomang Railway Bridge

Table 4. IWF Section Properties

\begin{tabular}{|c|c|c|c|c|c|}
\hline $\begin{array}{c}\text { IWF } \\
\text { Section }\end{array}$ & $\begin{array}{c}\mathrm{H} \\
(\mathrm{mm})\end{array}$ & $\begin{array}{c}\mathrm{B} \\
(\mathrm{mm})\end{array}$ & $\begin{array}{c}\mathrm{t}_{\mathrm{w}} \\
(\mathrm{mm})\end{array}$ & $\begin{array}{c}\mathrm{t}_{\mathrm{f} 1} \\
(\mathrm{~mm})\end{array}$ & $\begin{array}{c}\mathrm{t}_{\mathrm{f} 2} \\
(\mathrm{~mm})\end{array}$ \\
\hline $2022 \times 500$ & 2022 & 500 & 20 & 57 & 60 \\
\hline $1200 \times 700$ & 1200 & 700 & 20 & 40 & 40 \\
\hline $924 \times 400$ & 924 & 400 & 20 & 25 & 25 \\
\hline $283 \times 300$ & 283 & 300 & 7.5 & 10.5 & 10.5 \\
\hline
\end{tabular}

Table 5. Box Hollow Section Properties

\begin{tabular}{|c|c|c|c|c|c|}
\hline $\begin{array}{c}\text { Hollow } \\
\text { Section }\end{array}$ & $\begin{array}{c}\mathrm{H} \\
(\mathrm{mm})\end{array}$ & $\begin{array}{c}\mathrm{B} \\
(\mathrm{mm})\end{array}$ & $\begin{array}{c}\mathrm{t}_{\mathrm{w}} \\
(\mathrm{mm})\end{array}$ & $\begin{array}{c}\mathrm{t}_{\mathrm{f} 1} \\
(\mathrm{~mm})\end{array}$ & $\begin{array}{c}\mathrm{t}_{\mathrm{f} 2} \\
(\mathrm{~mm})\end{array}$ \\
\hline VB 1 & 500 & 460 & 36 & 18 & 18 \\
\hline VB 2 & 500 & 1000 & 70 & 25 & 25 \\
\hline VB 3 & 486 & 650 & 45 & 18 & 18 \\
\hline VB 4 & 500 & 650 & 60 & 45 & 45 \\
\hline VB 5 & 520 & 1420 & 20 & 35 & 35 \\
\hline Arch & 600 & 520 & 55 & 35 & 35 \\
\hline
\end{tabular}

Table 6. Tapered Box Section Properties

\begin{tabular}{|c|c|c|c|c|c|}
\hline $\begin{array}{c}\text { Tapered } \\
\text { Section }\end{array}$ & $\mathrm{H}(\mathrm{mm})$ & $\begin{array}{c}\mathrm{B} \\
(\mathrm{mm})\end{array}$ & $\begin{array}{c}\mathrm{t}_{\mathrm{w}} \\
(\mathrm{mm})\end{array}$ & $\begin{array}{c}\mathrm{t}_{\mathrm{f} 1} \\
(\mathrm{~mm})\end{array}$ & $\begin{array}{c}\mathrm{t}_{\mathrm{f} 2} \\
(\mathrm{~mm})\end{array}$ \\
\hline Arch - 1 & $600-1300$ & 520 & 55 & 35 & 35 \\
\hline Arch - 3 & $600-1000$ & 520 & 55 & 35 & 35 \\
\hline
\end{tabular}

\subsection{Dynamic Load on Bridge}

Dynamic load changes over time. There are 3 different types of dynamic load for bridge: moving load (Figure $6 a$ ), moving mass without stiffness and damping (Figure $6 \mathrm{~b}$ ) and moving mass with stiffness and damping (Figure 6c) as discussed in [3].

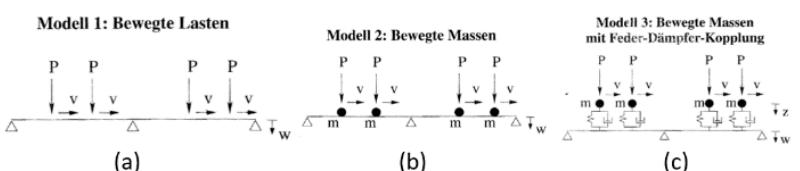

(a)

(b)

(c)

Fig. 6. Three types of Dynamic Load on Bridge [3]

Dynamic load used in this study is moving mass with stiffness and damping, so that the train load is calculated first which follow SDOF model as shown in Figure 7. Bridge resist train load $f_{T}$ which follows equation (1).

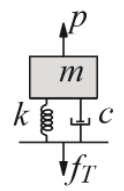

Fig. 7. Train Load Model [1]

$$
f_{T}=k u+c \dot{u}
$$

Where :

$f_{T}$ : force transferred to bridge ( $\left.\mathrm{N}\right)$

$k:$ stiffness $(\mathrm{N} / \mathrm{m})$ 
$C:$ damping ratio $(\mathrm{N} . \mathrm{s} / \mathrm{m})$

$u:$ displacement $(\mathrm{m})$

$\dot{u}$ : velocity $(\mathrm{m} / \mathrm{s})$

Displacement and velocity are derived from SDOF equation

$$
m \cdot \ddot{u}+c \cdot \dot{u}+k \cdot u=p_{o}
$$

Which has the solution $u(t)$

$$
u(t)=e^{-\xi \omega t}\left(A_{1} \cos \omega_{D} t+A_{2} \sin \omega_{D} t\right)+\frac{p_{0}}{K}
$$

And the solution $\dot{u}(t)$

$$
\begin{aligned}
\dot{u}(t)= & e^{-\xi \omega t}\left(-A_{1} \omega_{D} \sin \omega_{D} t+A_{2} \omega_{D} \cos \omega_{D} t\right) \\
& +(-\xi \omega) e^{-\xi \omega t}\left(A_{1} \cos \omega_{D} t+A_{2} \sin \omega_{D} t\right)
\end{aligned}
$$

So that in the end, we can get train load function Ft as shown in Figure 8

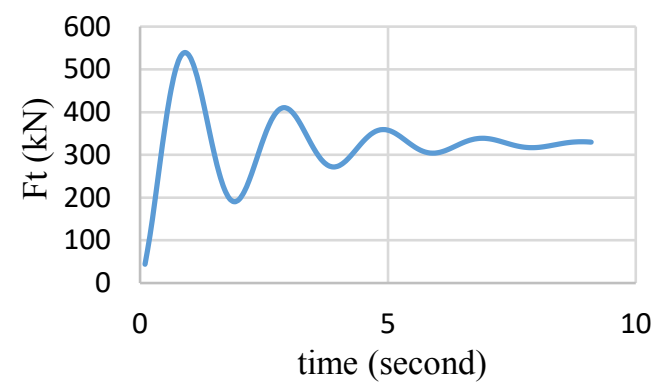

Fig. 8. Ft Load Function

Ft load function (Figure 8) must be applied to specific node on the bridge span. The load is concentrated load from the weight of train wagon which has distance as shown in Figure 9. So, in this model train load will be applied to 24 nodes on the bridge span as shown in Figure 10 , which has distance approximately $10 \mathrm{~m}$ between nodes. Ft load function (Figure 8) is applied on the specific node from those 24 nodes so that the new function must be derived which represent load function for each node. To derived load function for specific node, train time arrival at that specified node must be determined first. Train time arrival at specified node depends on speed of the train. There will be 24 load functions for 1 speed train for 1 bridge model. Because there are 4 speed variations, in the end there are 96 load functions in total. As an example, the load calculation for node 1210 which is located at the middle of the span will be shown in Table 7 (for $50 \mathrm{~km} /$ hour), Table 8 (for $100 \mathrm{~km} /$ hour), Table 9 (for $150 \mathrm{~km} /$ hour), and Table 10 (for $200 \mathrm{~km} /$ hour). The functions shown in Figure 11 to 14 will be applied to node 1210 .

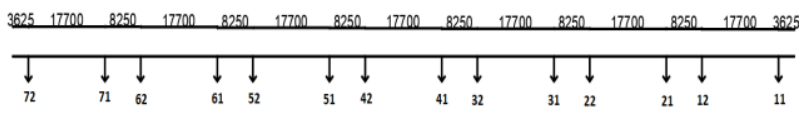

Fig. 9. Train's Wagon Distance

\section{1 \2 11111111111!}

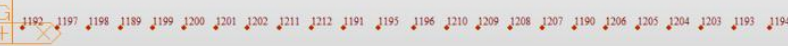

Fig. 10. Twenty Four Nodes to be Applied Train Load
Table 7. Load Calculation for Node at The Middle of The Span (Speed of Train $50 \mathrm{~km} /$ hour)

\begin{tabular}{|c|c|c|c|}
\hline Nodal 1210 & Distance $(\mathrm{m})$ & Time $(\mathrm{s})$ & Load $(\mathrm{kN})$ \\
\hline Wagon 11 & 144.88 & 10.43 & 325.12 \\
\hline Wagon 12 & 162.58 & 11.71 & 324.24 \\
\hline Wagon 21 & 170.83 & 12.30 & 324.78 \\
\hline Wagon 22 & 188.53 & 13.57 & 325.07 \\
\hline Wagon 31 & 196.78 & 14.17 & 324.93 \\
\hline Wagon 32 & 214.48 & 15.44 & 325.31 \\
\hline Wagon 41 & 222.73 & 16.04 & 325.10 \\
\hline Wagon 42 & 241.01 & 17.35 & 325.33 \\
\hline Wagon 51 & 248.68 & 17.90 & 325.22 \\
\hline Wagon 52 & 266.38 & 19.18 & 325.34 \\
\hline Wagon 61 & 274.63 & 19.77 & 325.27 \\
\hline Wagon 62 & 292.33 & 21.05 & 325.32 \\
\hline Wagon 71 & 300.58 & 21.64 & 325.29 \\
\hline Wagon 72 & 318.28 & 22.92 & 325.31 \\
\hline
\end{tabular}

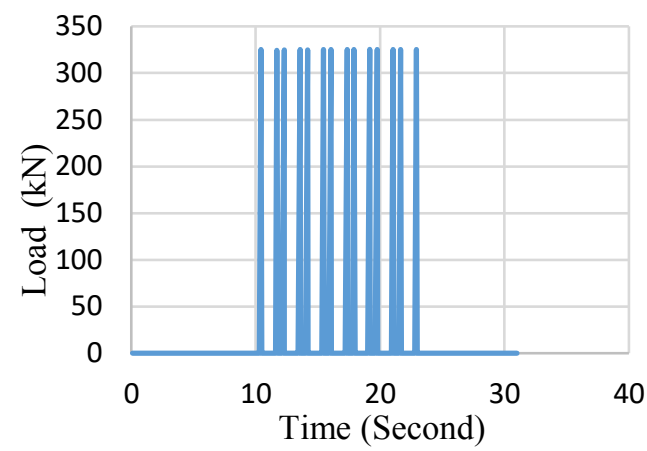

Fig. 11. Load Function for Node at The Middle of The Span (Speed of Train $50 \mathrm{~km} /$ hour)

Table 8. Load Calculation for Node at The Middle of The Span (Speed of Train $100 \mathrm{~km} / \mathrm{hour}$ )

\begin{tabular}{|c|c|c|c|}
\hline Nodal 1210 & Distance $(\mathrm{m})$ & Time $(\mathrm{s})$ & Load $(\mathrm{kN})$ \\
\hline Wagon 11 & 144.88 & 5.22 & 345.46 \\
\hline Wagon 12 & 162.58 & 5.85 & 304.27 \\
\hline Wagon 21 & 170.83 & 6.15 & 309.57 \\
\hline Wagon 22 & 188.53 & 6.79 & 337.76 \\
\hline Wagon 31 & 196.78 & 7.08 & 336.80 \\
\hline Wagon 32 & 214.48 & 7.72 & 318.33 \\
\hline Wagon 41 & 222.73 & 8.02 & 317.32 \\
\hline Wagon 42 & 241.01 & 8.68 & 329.18 \\
\hline Wagon 51 & 248.68 & 8.95 & 330.60 \\
\hline Wagon 52 & 266.38 & 9.59 & 323.66 \\
\hline Wagon 61 & 274.63 & 9.89 & 321.93 \\
\hline Wagon 62 & 292.33 & 10.52 & 325.87 \\
\hline Wagon 71 & 300.58 & 10.82 & 327.35 \\
\hline Wagon 72 & 318.28 & 11.46 & 325.27 \\
\hline
\end{tabular}

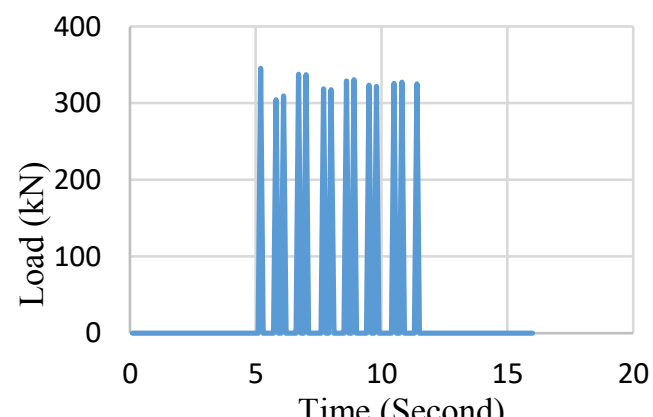

Fig. 12. Load Function for Node at The Middle of The Span (Speed of Train $100 \mathrm{~km} / \mathrm{hour}$ ) 
Table 9. Load Calculation for Node at The Middle of The Span (Speed of Train $150 \mathrm{~km} / \mathrm{hour}$ )

\begin{tabular}{|c|c|c|c|}
\hline Nodal 1210 & Distance $(\mathrm{m})$ & Time $(\mathrm{s})$ & Load $(\mathrm{kN})$ \\
\hline Wagon 11 & 144.88 & 3.48 & 320.39 \\
\hline Wagon 12 & 162.58 & 3.90 & 271.62 \\
\hline Wagon 21 & 170.83 & 4.10 & 280.82 \\
\hline Wagon 22 & 188.53 & 4.52 & 334.37 \\
\hline Wagon 31 & 196.78 & 4.72 & 353.19 \\
\hline Wagon 32 & 214.48 & 5.15 & 350.40 \\
\hline Wagon 41 & 222.73 & 5.35 & 334.59 \\
\hline Wagon 42 & 241.01 & 5.78 & 305.62 \\
\hline Wagon 51 & 248.68 & 5.97 & 304.35 \\
\hline Wagon 52 & 266.38 & 6.39 & 322.06 \\
\hline Wagon 61 & 274.63 & 6.59 & 331.90 \\
\hline Wagon 62 & 292.33 & 7.02 & 337.99 \\
\hline Wagon 71 & 300.58 & 7.21 & 333.37 \\
\hline Wagon 72 & 318.28 & 7.64 & 319.96 \\
\hline
\end{tabular}

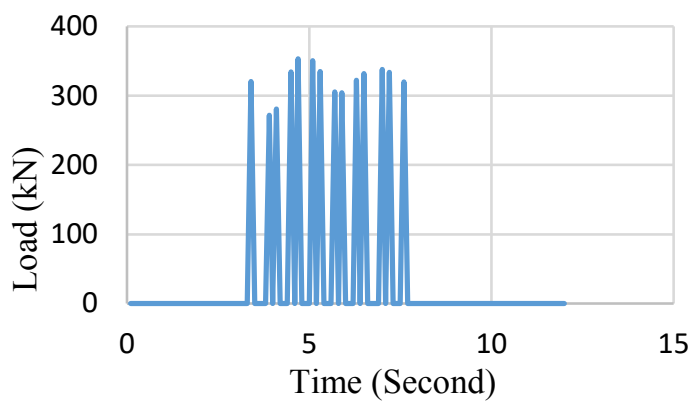

Fig. 13. Load Function for Node at The Middle of The Span (Speed of Train $150 \mathrm{~km} / \mathrm{hour}$ )

Table 10. Load Calculation for Node at The Middle of The Span (Speed of Train $200 \mathrm{~km} / \mathrm{hour}$ )

\begin{tabular}{|c|c|c|c|}
\hline Nodal 1210 & Distance $(\mathrm{m})$ & Time $(\mathrm{s})$ & Load $(\mathrm{kN})$ \\
\hline Wagon 11 & 144.88 & 2.61 & 371.34 \\
\hline Wagon 12 & 162.58 & 2.93 & 410.28 \\
\hline Wagon 21 & 170.83 & 3.07 & 399.21 \\
\hline Wagon 22 & 188.53 & 3.39 & 338.17 \\
\hline Wagon 31 & 196.78 & 3.54 & 307.66 \\
\hline Wagon 32 & 214.48 & 3.86 & 272.20 \\
\hline Wagon 41 & 222.73 & 4.01 & 274.32 \\
\hline Wagon 42 & 241.01 & 4.34 & 309.53 \\
\hline Wagon 51 & 248.68 & 4.48 & 328.29 \\
\hline Wagon 52 & 266.38 & 4.79 & 356.95 \\
\hline Wagon 61 & 274.63 & 4.94 & 358.93 \\
\hline Wagon 62 & 292.33 & 5.26 & 341.74 \\
\hline Wagon 71 & 300.58 & 5.41 & 328.95 \\
\hline Wagon 72 & 318.28 & 5.73 & 307.46 \\
\hline
\end{tabular}

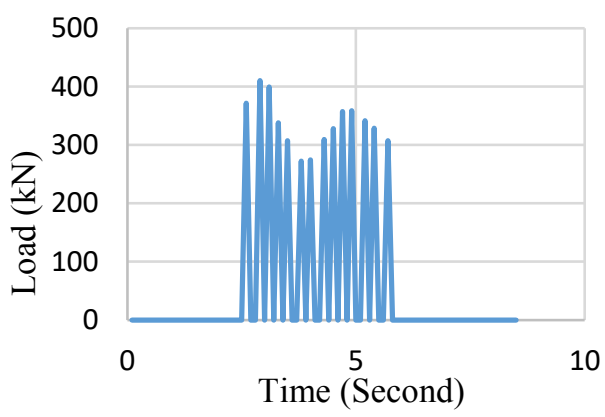

Fig. 14. Load Function for Node at The Middle of The Span (Speed of Train $200 \mathrm{~km} / \mathrm{hour}$ )

\subsection{Tuned Mass Damper}

\subsubsection{Tuned Mass Damper Mechanism}

The purpose of adding the mass damper is to limit the motion of the structure with the mechanism is represented in Figure 15 [2].

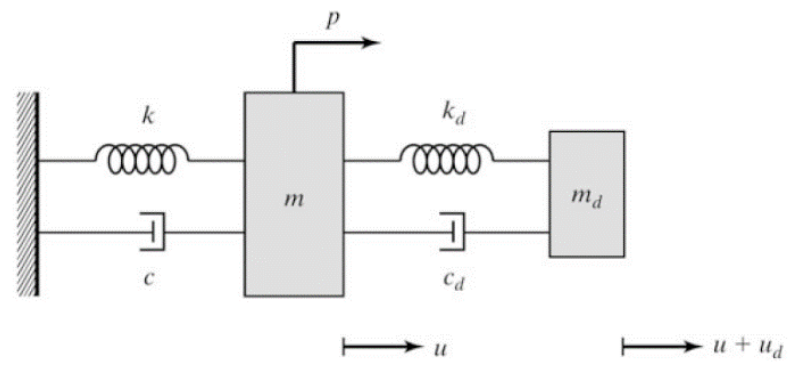

Fig. 15. TMD Mechanism in SDOF [2]

$$
\begin{gathered}
\omega^{2}=\frac{k}{m} \\
c=2 \xi \omega m \\
\omega_{d}^{2}=\frac{k_{d}}{m_{d}} \\
c_{d}=2 \xi_{d} \omega_{d} m_{d}
\end{gathered}
$$

And defining $\bar{m}$ as the mass ratio,

$$
\bar{m}=\frac{m_{d}}{m}
$$

The governing equations of motion are given by

$$
\begin{aligned}
& \text { Tuned mass } \ddot{u}_{d}+2 \xi_{d} \omega_{d} \dot{u}_{d}+\omega_{d}^{2} u_{d}=-\ddot{u} \\
& \text { Primary mass }(1+\bar{m}) \ddot{u}+2 \xi \omega \dot{u}+\omega^{2} u=\frac{P}{m}-\bar{m} \ddot{u}_{d}
\end{aligned}
$$

\subsubsection{Tuned Mass Damper Planning}

Dimension of tuned mass damper used in this study refers to manufacturer as shown in Table 11. Selection of tuned mass damper is limited by the distance between upper structure (beam) and the arch which are $1.3 \mathrm{~m}$ length. Mass, stiffness and damping of TMD become the input into the structural modelling. TMD $1500 \mathrm{~kg}$ is used in $1 \%$ mass ratio model and TMD $2000 \mathrm{~kg}$ is used in $1.6 \%$ mass ratio model.

Table 11. Tuned Mass Damper Dimension [8]

\begin{tabular}{|c|c|c|c|}
\hline $\begin{array}{c}\text { Tuned } \\
\text { mass }(\mathrm{kg})\end{array}$ & $\begin{array}{c}\text { Length } \\
(\mathrm{mm})\end{array}$ & $\begin{array}{c}\text { Width } \\
(\mathrm{mm})\end{array}$ & $\begin{array}{c}\text { Height } \\
(\mathrm{mm})\end{array}$ \\
\hline 250 & 620 & 200 & 635 \\
\hline 500 & 870 & 200 & 735 \\
\hline 750 & 1020 & 200 & 905 \\
\hline 1000 & 1220 & 200 & 935 \\
\hline 1500 & 1420 & 240 & 1005 \\
\hline 2000 & 1620 & 240 & 1085 \\
\hline 2500 & 1750 & 250 & 1185 \\
\hline 3000 & 1870 & 250 & 1285 \\
\hline 4000 & 2120 & 280 & 1585 \\
\hline 5000 & 2320 & 280 & 1705 \\
\hline 6000 & 2520 & 280 & 1785 \\
\hline
\end{tabular}




\section{Results and Discussion}

Table 12 shows the periods of the structure and Figure 16 to 17 show the structural mode shape.

Table 12. Periods of Structure

\begin{tabular}{|c|c|c|c|}
\hline Mode & $\begin{array}{c}\text { Frequency } \\
\text { (rad/sec) }\end{array}$ & $\begin{array}{c}\text { Frequency } \\
\text { (cycle/sec) }\end{array}$ & $\begin{array}{c}\text { Period } \\
\text { (sec) }\end{array}$ \\
\hline 1 & 3,2698 & 0,5204 & 1,9215 \\
\hline 2 & 6,5598 & 1,0440 & 0,9578 \\
\hline
\end{tabular}

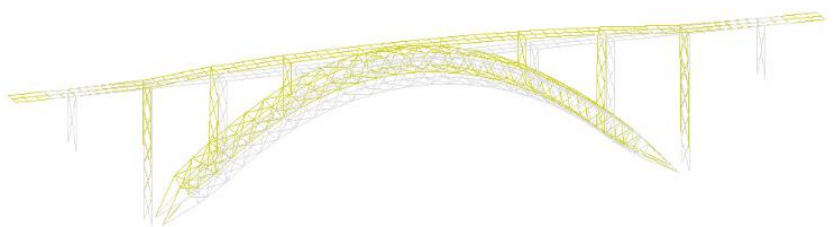

Fig. 16. First Mode Shape of Structure

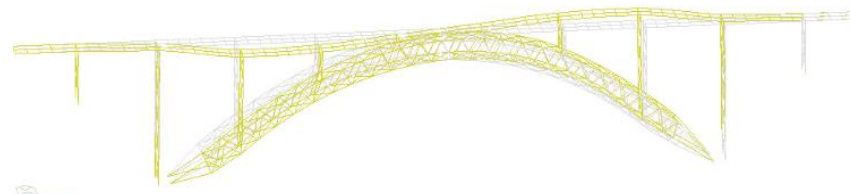

Fig. 17. Second Mode Shape of Structure

The whole mass of the bridge including the arch is taken into account while planning TMD because the arch also deformed (not a rigid body). Figure 18 shows the structure's deformation due to static load.

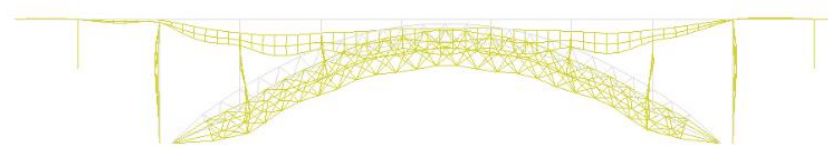

Fig. 18. Deformation of Structure due to Static Load

\subsection{Dynamic Responses of Structure without TMD}

Dynamic responses which are under reviewed in this study are displacement and acceleration.

\subsubsection{Displacement}

In this study, displacement of structure at the middle of the span is being concerned. Speed of the train influences displacement of the structure. Table 13 and Figure 19 shows the displacement value for each train's speed.

Table 13. Maximum Displacement for each Speed of Train

\begin{tabular}{|c|c|}
\hline $\begin{array}{c}\text { Speed of the Train } \\
(\mathrm{km} / \text { hour })\end{array}$ & $\begin{array}{c}\text { Displacement } \\
(\mathrm{m})\end{array}$ \\
\hline 50 & $-0,00419$ \\
\hline 100 & $-0,00689$ \\
\hline 150 & $-0,0071$ \\
\hline 200 & $-0,00917$ \\
\hline
\end{tabular}

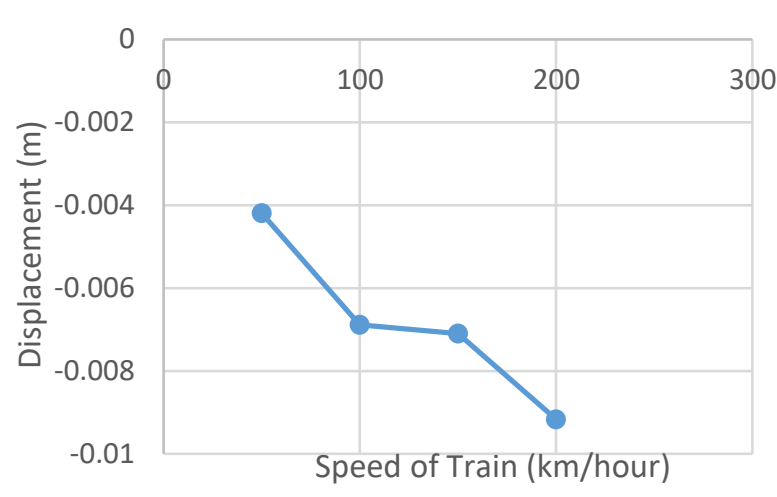

Fig. 19. Maximum Displacement for each Speed of Train

According to PM 602012 "Persyaratan Teknis Jalur Kereta Api" [10], maximum deflection limit is L/1000 which is 244.3 meter/1000 $=0.244$ meter. Maximum deflection of structure is less than the limitation so it can be concluded that the structure is acceptable in deformation.

\subsubsection{Acceleration}

Based on its maximum acceleration, structure must fulfils safety level and serviceability level. Structure is acceptable safe if its acceleration is less than $3.5 \mathrm{~m} / \mathrm{s}^{2}$ based on Eurocode EN 1990:2002 [5] and acceptable in serviceability comfort level if its acceleration is less than $2 \mathrm{~m} / \mathrm{s}^{2}$ based on DIN-Fachbericht 101 Einwirkungen au Brücken [4]. Figure 20 shows maximum structure's acceleration for each speed of train. Structure fulfil both of the safety and serviceability level only for $50 \mathrm{~km} /$ hour speed of train.

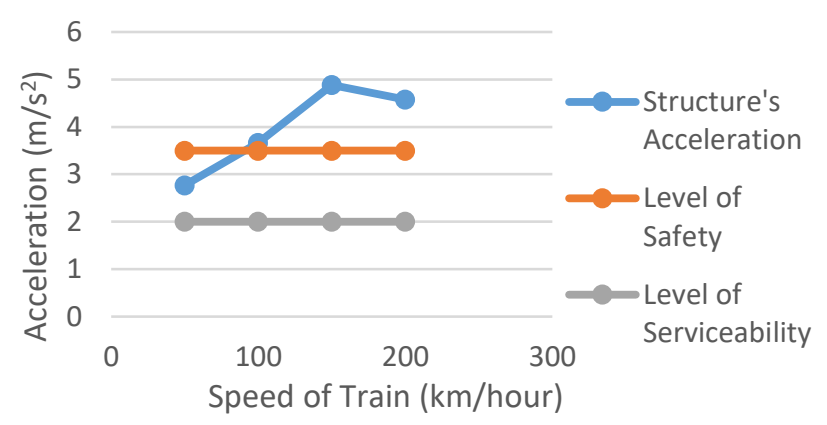

Fig. 20. Maximum Acceleration for each Speed of Train

The structure is not safe for $100 \mathrm{~km} /$ hour, $150 \mathrm{~km} /$ hour and $200 \mathrm{~km} /$ hour speed of train. Because the acceleration of structure exceeds the maximum limit of safety due to high speed train, tuned mass damper will be used to reduce it.

\subsection{Dynamic Responses of Structure with TMD}

Generally, for all variations, TMD is proven reduce Cisomang Railway Bridge's response. As an illustration, Figure 21 shows how significance 1.6\% TMD reduce Cisomang Railway Bridge's response when it is placed in max deformation of second mode and set to first mode frequency. 


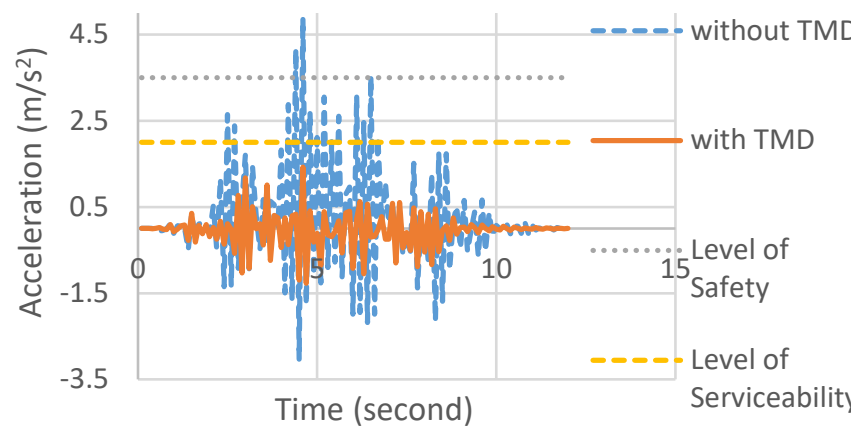

Fig. 21. TMD Reduces Cisomang Railway Bridge's Acceleration

Furthermore, as described before in Chapter 2, TMD will be varied to find which one is the most effective. TMD will be placed at maximum deformation of first mode for Model 1, 2, 5, 6 as shown in Figure 22 and placed at maximum deformation of second mode for Model 3, 4, 7, 8 as shown in Figure 23. Furthermore, TMD will be varied in mass and frequency setting.

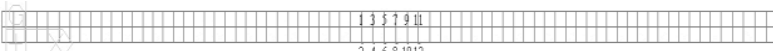

Fig. 22. TMD Location for Model 1, 2, 5, 6

\section{HAN}

Fig. 23. TMD Location for Model 3, 4, 7, 8

\subsubsection{The used of TMD $1 \%$ Mass Ratio}

For $1 \%$ mass ratio, 12 TMD are installed which have properties follow Table 14 . In this sub chapter ( $1 \%$ mass ratio of TMD), Model 1 until 4 are under reviewed.

Table 14. Properties of TMD $1 \%$ Mass Ratio

\begin{tabular}{|c|c|c|c|}
\hline & $\begin{array}{c}\text { First Mode } \\
\text { Natural Frequency }\end{array}$ & $\begin{array}{c}\text { Second Mode } \\
\text { Natural Frequency }\end{array}$ & \\
\hline $\mathrm{M}_{\mathrm{T}}$ & 1,337 & 1,337 & ton \\
\hline $\mathrm{K}_{\mathrm{T}}$ & 14,152 & 56,9585 & $\mathrm{kN} / \mathrm{m}$ \\
\hline $\mathrm{D}_{\mathrm{T}}$ & 0,53144 & 1,0661 & $\mathrm{kN} . \mathrm{s} / \mathrm{m}$ \\
\hline
\end{tabular}

From these variations, it can be concluded that TMD reduce the structure's acceleration. Previously, structure is safe if only the speed of the train $50 \mathrm{~km} /$ hour. After the used of $1 \%$ mass ratio of TMD, structure becomes safe for $50 \mathrm{~km} /$ hour, $100 \mathrm{~km} /$ hour, $150 \mathrm{~km} /$ hour and $200 \mathrm{~km} /$ hour. But, all the structures still not fulfil serviceability comfort level. This can be summarized in Figure 24 and 25.

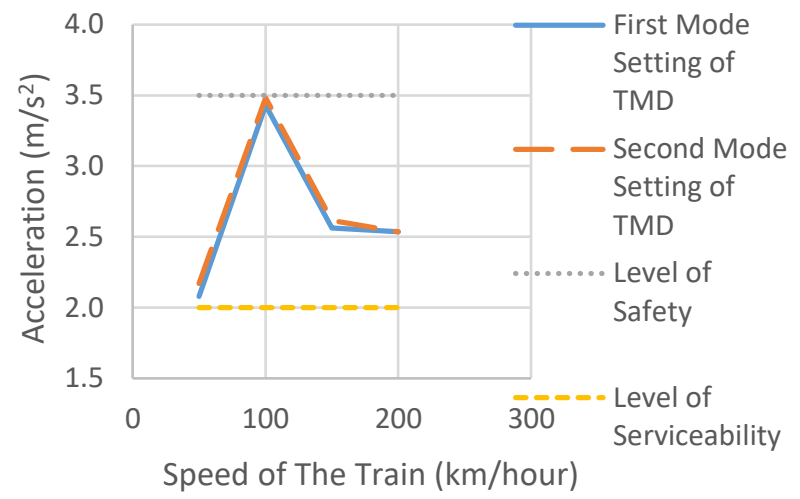

Fig. 24. The Effect of The Used of TMD 1\% Mass Ratio Placed at The Maximum Deformation of First Mode on Structure's Acceleration (Model 1 and 2)

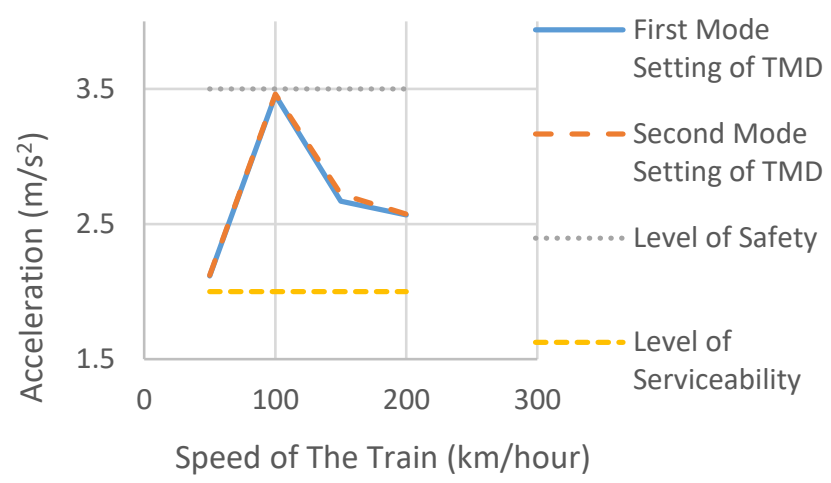

Fig. 25. The Effect of The Used of TMD 1\% Mass Ratio Placed at The Maximum Deformation of Second Mode on Structure's Acceleration (Model 3 and 4)

\subsubsection{The used of TMD 1.6\% Mass Ratio}

For $1.6 \%$ mass ratio, 13 TMD are installed which have properties follow Table 15 . In this sub chapter $(1.6 \%$ mass ratio of TMD), Model 5 until 8 are under reviewed.

Table 15. Properties of TMD 1.6\% Mass Ratio

\begin{tabular}{|c|c|c|c|}
\hline & $\begin{array}{c}\text { First Mode } \\
\text { Natural Frequency }\end{array}$ & $\begin{array}{c}\text { Second Mode } \\
\text { Natural Frequency }\end{array}$ & \\
\hline $\mathrm{M}_{\mathrm{T}}$ & 1,9747 & 1,9747 & ton \\
\hline $\mathrm{K}_{\mathrm{T}}$ & 20.7757 & 83.6185 & $\mathrm{kN} / \mathrm{m}$ \\
\hline $\mathrm{D}_{\mathrm{T}}$ & 0,9879 & 1,981 & $\mathrm{kN} . \mathrm{s} / \mathrm{m}$ \\
\hline
\end{tabular}

Once again, from these variations, it can be concluded that TMD reduce the structure's acceleration. Previously, all the structures do not satisfy serviceability requirement in the used of $1 \%$ mass ratio of TMD. After the used of $1.6 \%$ mass ratio of TMD, structure meet the requirement for $50 \mathrm{~km} /$ hour, $150 \mathrm{~km} /$ hour and $200 \mathrm{~km} /$ hour but still not satisfy for $100 \mathrm{~km} /$ hour. This can be summarized in Figure 26 and 27. 


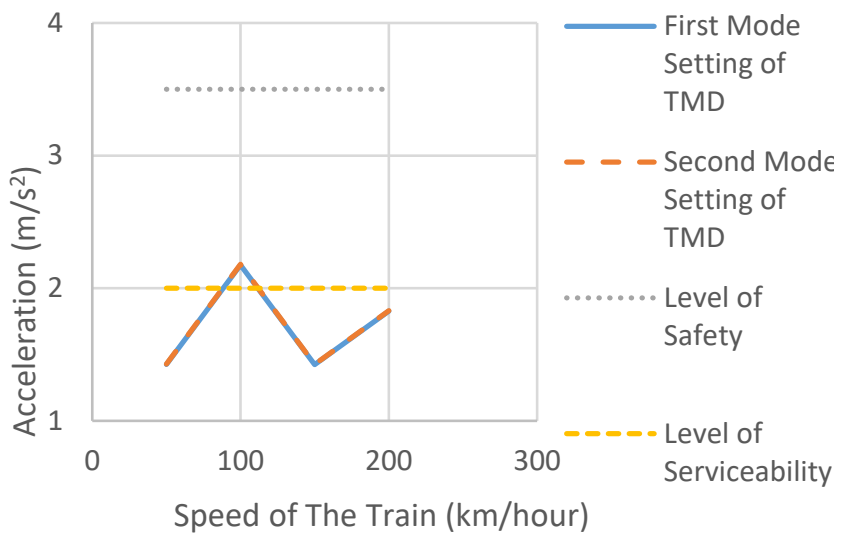

Fig. 26. The Effect of The Used of TMD 1.6\% Mass Ratio Placed at The Maximum Deformation of First Mode on Structure's Acceleration (Model 5 and 6)

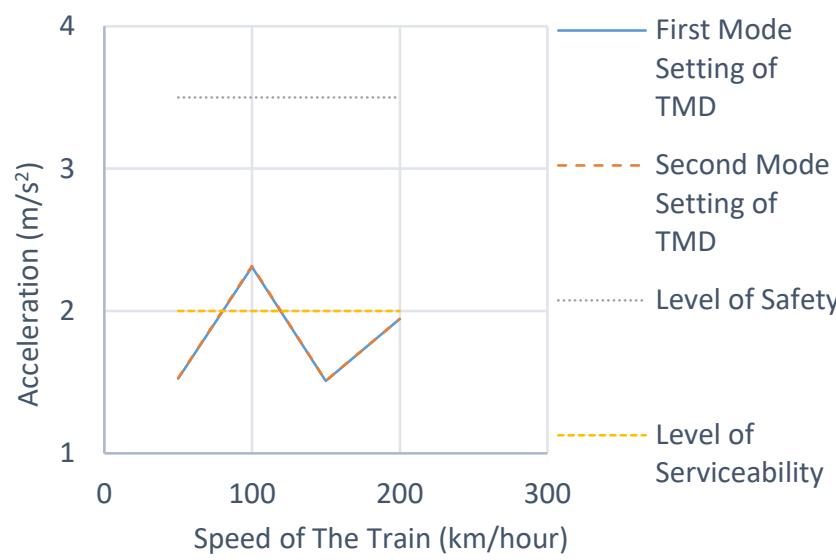

Fig. 27. The Effect of The Used of TMD 1.6\% Mass Ratio Placed at The Maximum Deformation of First Mode on Structure's Acceleration (Model 7 and 8)

\subsubsection{The Effectiveness of Tuned Mass Damper}

How significance TMD reduces the structure's responses is summarized in Figure 28. The used of 1.6\% TMD mass ratio gives the best result. And the best effective is given by the used of TMD which is tuned to the first mode. The largest decrease in structure's acceleration is when the bridge crossed by the train which has velocity 150 $\mathrm{km} /$ hour.

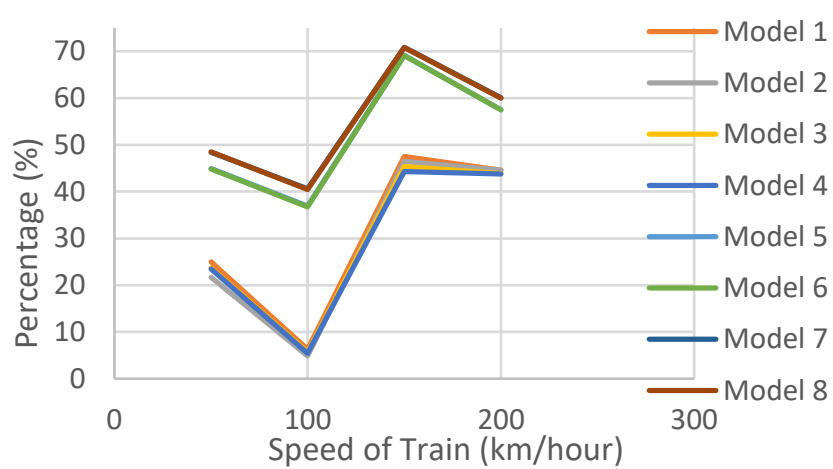

Fig. 28. The Effectiveness of TMD

\subsubsection{Dominant Frequency Analysis using Fast Fourier Transform}

The data used for FFT is structure's acceleration without TMD. The acceleration graphs from FFT will be shown only the natural frequency part to find out the most dominant natural frequency. From Figure 29 and Table 16 , amplitudes of first natural frequency always larger than the second natural frequency. So, it can be concluded that first mode is more dominant than second mode. It is the reason why TMD tuned to first mode is more effective than to second mode. Moreover, amplitudes from FFT analysis for $150 \mathrm{~km} /$ hour speed of train are largest than the other speed of train. It is the reason why the largest decrease in structure's acceleration is when the bridge crossed by the train which has velocity $150 \mathrm{~km} /$ hour. (a)

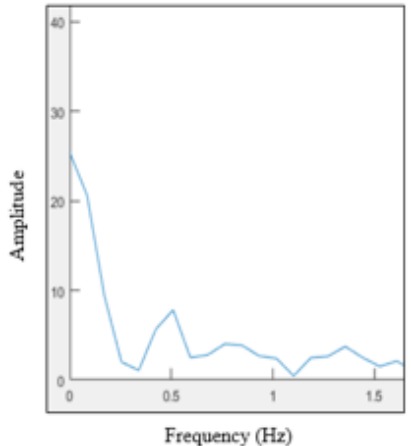

(c)

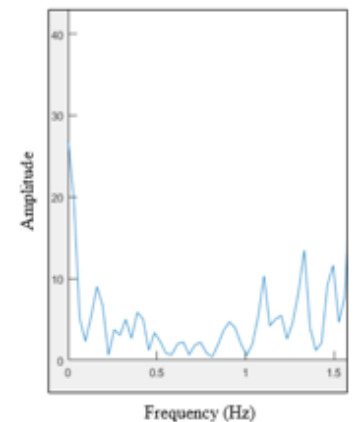

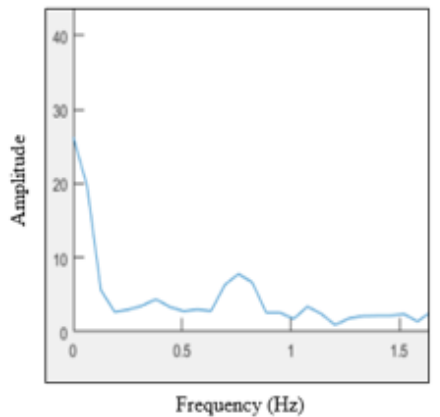

(b)

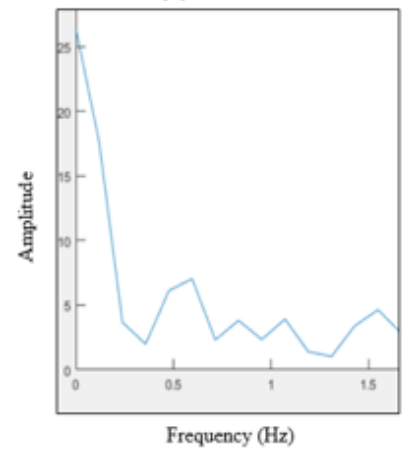

(d)
Fig. 29. Acceleration Graph from FFT Analysis for Each Speed of The Train (a) $50 \mathrm{~km} /$ hour (b) $100 \mathrm{~km} /$ hour (c) 150 $\mathrm{km} /$ hour (d) $200 \mathrm{~km} /$ hour

Table 16. Amplitude Vs Natural Frequency

\begin{tabular}{|l|c|c|}
\cline { 2 - 3 } \multicolumn{1}{c|}{} & \multicolumn{2}{c|}{ Amplitude } \\
\cline { 2 - 3 } \multicolumn{1}{c|}{} & $1^{\text {st }}$ Natural Frequency & $2^{\text {nd }}$ Natural Frequency \\
\hline $50 \mathrm{~km} / \mathrm{hr}$ & 2.273 & 1.983 \\
\hline $100 \mathrm{~km} / \mathrm{hr}$ & 2.769 & 1.733 \\
\hline $150 \mathrm{~km} / \mathrm{hr}$ & 7.819 & 0.567 \\
\hline $200 \mathrm{~km} / \mathrm{hr}$ & 6.32 & 4.231 \\
\hline
\end{tabular}

\subsubsection{Resonance Checking}

Resonance will occur if the structure frequency same as the load frequency. Resonance may cause collapse to structure. From Table 17, the natural frequency of structure different to the load frequency so that it can be concluded that resonance does not occur. 
Table 17. Resonance Checking

\begin{tabular}{|c|c|c|c|c|}
\hline \multirow{2}{*}{$\begin{array}{c}\text { Natural } \\
\text { Frequency }\end{array}$} & \multicolumn{4}{|c|}{ Load Frequency } \\
\cline { 2 - 5 } & $50 \mathrm{~km} / \mathrm{hr}$ & $100 \mathrm{~km} / \mathrm{hr}$ & $150 \mathrm{~km} / \mathrm{hr}$ & $200 \mathrm{~km} / \mathrm{hr}$ \\
\hline 0.520 & 0.785 & 1.569 & 2.354 & 3.139 \\
\hline 1.044 & 0.535 & 1.070 & 1.606 & 2.141 \\
\hline & 0.318 & 0.636 & 0.955 & 1.273 \\
\hline & 0.268 & 0.535 & 0.803 & 1.070 \\
\hline & 0.200 & 0.399 & 0.599 & 0.798 \\
\hline & 0.178 & 0.357 & 0.535 & 0.714 \\
\hline & 0.145 & 0.291 & 0.436 & 0.582 \\
\hline & 0.134 & 0.268 & 0.401 & 0.535 \\
\hline & 0.114 & 0.229 & 0.343 & 0.457 \\
\hline & 0.107 & 0.214 & 0.321 & 0.428 \\
\hline & 0.094 & 0.188 & 0.283 & 0.377 \\
\hline & 0.089 & 0.178 & 0.268 & 0.357 \\
\hline & 0.080 & 0.160 & 0.240 & 0.320 \\
\hline
\end{tabular}

\section{Conclusions}

Without TMD, Cisomang Railway Bridge still fulfils the Indonesian Government Criterion based on PM 60 - 2012 by its deformation but does not meet requirement of comfort criteria based on DIN-Fachbericht 101 by its acceleration. Furthermore, without TMD, only for the speed train $50 \mathrm{~km} / \mathrm{h}$ dynamic responses of structure fulfil safety criteria based on Eurocode EN 1990:2002, whereas the other speed variations do not meet that requirement. TMD reduce the structure's acceleration. After the use of TMD 1\% mass ratio, the structure fulfils the safety criteria for all speed train variations, which previously only for 50 $\mathrm{km} /$ hour for structure without TMD. It can be concluded that the use of $1 \%$ TMD mass ratio is enough to fulfil safety level but still not enough to fulfil comfort level. After the use of TMD 1.6\% mass ratio, all the structure fulfils the safety and comfort criteria except $100 \mathrm{~km} / \mathrm{h}$ speed only fulfils the safety criteria. Tuned mass damper which is tuned to first mode as the most dominant mode gives the most effective result.

The authors wish to thank the Department of Civil Engineering, Parahyangan Catholic University for facilitating the finite element software that was employed in this numerical study.

\section{References}

1. A. K. Chopra, Dynamics of Structures Theory and Applications to Earthquake Engineering, E 4 (University of California at Berkeley, 2011)

2. J.Connor, S. Laflamme, Structural Motion Engineering (Springer, 2014)

3. D. Dinkler, M. Löhr, Resonanzgefährdung von Eisenbahnbrückenbei Hochgeschwindigkeitsüber fahrten, Berichte der Fachtgung Baustatik-Baupraxis 9 (Dresden, 2005)

4. DIN-Fachbericht 101, Einwirkungen auf Brücken (Berlin, 2003)

5. EN 1990 Annex A2. European Committee for Standardization, Basic of Structural Design. Application for Bridges (Normative) (Berlin, 2002)
6. H. C. Kwon, M. C. Kim, I.W. Lee, Vibration Control of Bridges Under Moving Loads, Computers \& Structures 66, 473-480 (1998)

7. J. F. Wang, C. C. Lin, B. L. Chen, Vibration Suppression for High-speed Railway Bridges Using Tuned Mass Dampers, International Journal of Solids and Structures 40, 465-491 (2003)

8. MAURER SÖHNE, Maurer Tuned Mass and Viscous Dampers, Technical Information and product (2011)

9. N. Zhang, Y. Tian, H. Xia, A Train-Bridge Dynamic Interaction Analysis Method and Its Experimental Validation, Engineering 2, 528-536 (2016)

10. PM 60 - 2012. Persyaratan Teknis Jalur Kereta Api (2012) 